\title{
Proprietary Value in Shiite Jurisprudence and Positive Law of the Islamic Republic of Iran
}

\author{
Atefeh Lorkojuri ${ }^{1}$, Mohamad Ali Heidari ${ }^{1}$ \& Masoud Raei ${ }^{1}$ \\ ${ }^{1}$ Department of Law and Theology, Najafabad Branch, Islamic Azad University, Najafabad, Iran \\ Correspondence: Mohamad Ali Heidari, Department of Law and Theology, Najafabad Branch, Islamic Azad \\ University, Najafabad, Iran. E-mail: ma.jeidari13@yahoo.com
}

Received: July 12, 2016

doi:10.5539/jpl.v9n9p41
Accepted: July 26, 2016 Online Published: October 30, 2016

URL: http://dx.doi.org/10.5539/jpl.v9n9p41

\begin{abstract}
Proprietary value is one of the conditions related to the considerations (price and sold object) in a sale contract. Property has been defined by legal experts in several ways including the idea that property should have the capability to be changed to money, to have value, and to be demanded by human will. According to Article 348 of Civil Code of the Islamic Republic of Iran, the sale of something that is not (describable as) property or which can bring no reasonable profit is null. In this regard, time and place circumstances play an important role in the determination of proprietary value. Famous legal experts and jurists have proposed different ideas about proprietary value so that the criterion for identification of proprietary value of a good has been regarded either religious or customary. This article tries to introduce proprietary value, time and place circumstances, and different ideas about proprietary value as a condition for contracts.
\end{abstract}

Keywords: proprietary value, personal value, customary value

\section{Introduction}

The subject of property and its measures have few been studied by researchers; most researches have focused on issues such as Islam's perspective toward property and ownership. Acquisition of property is permitted in Islam in terms of both quality and quantity. However, Islam has introduced some limitations and it obliges the Muslims to obey some limitations and pay attention to its definition in both practice and determination of instances. Islam has described property with adjectives like 'strength; and 'rise'in relation to people's life and it has been regarded as an instrument to organize lives and modify livings. These descriptions show the Islamic definition and concept of property as well as its rules. Property should circulate among people since Islam prohibits circulation of properties among a specific small group of people; it devotes a critical role to governments. Islam knows property as a divine load in the hands of creatures as it belongs to God. In this regard, it stipulates some conditions and provisions for consuming properties. Islam argues that a property will be a cause for the collapse of human societies if it displaces from it proper position; other wise, it will be a support for the owners of lives. Maintaining a balance in relation to property is very important in Islam so that property will become anti-property if it increases in any form and in any environment. Acquisition of properties in multiplication methods is unlawful and illegitimate and it is an instrument to oppress common people. It reflects the importance of discussions in this regard because the adverse consequences of disregarding the limitations and measures of property (holy businesses) are imposed on common people and they disturb social harmony. The knowledge of these limitations and provisions reveals the importance of property, its circulation, and its conditions in community in both personal and social terms. These practices found the Islamic school of economy.

\section{Literal and Expressional Definitions of Proprietary Value}

\subsection{Literal Definition of Proprietary Value}

In Arabic, the term property has been defined as "كل ماملكت من الاشياء فهومال" meaning property is everything that is possessed by human beings (Al-Waseti, 1985). The word property is derived from a past verb meaning to demand. Everybody who has property is called property holder; everything that has the capability to be possessed by persons and attracts people has proprietary value. In general, property is used as an objective essence and some jurists have brought this definition (Shahidi Tabrizi, 1996); they refer to a sentence in Majmaol Bahrain, "Shahidi Tabrizi" (Tarihi, 2000). This expression states that property is an objective form and possessed 
by people. In other words, estate has been used to define property. It seems that this definition is problematic because the meaning of estate is not clearer than the meaning of property while the definition should provide a more obvious implication. Since one can neglect such problems, it is not addressed in this study.

\subsection{Customary Definition of Proprietary Value}

In customary traditions, proprietary value is derived from an object while the object is demanded by individuals.

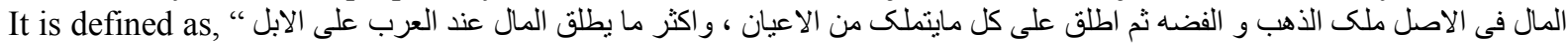
"الانها كانت اكثر امو الهم ". It says that it was first called to an amount of Gold or silver earned by people; then, it was used for any object that fulfills individuals' needs. For Arabs, camel is property (ibid: 363). Therefore, the meaning of property is clear for common people; every object that can be owned by them. In customary expressions, property includes any type of object that people are to pay money or a valuable object for it. Customs knows an object as a property when it is regarded by common people as property. However, some objects have proprietary value (and custom regards them as property), but they are not included in the instances of property according religious doctrines such as wine and carrion. Hence, it is necessary to describe the religious implication of proprietary value.

\section{Proprietary Value in Shiite Jurisprudence}

Besides literal meaning of a term, the experts in every field present an expressional definition for it. Jurists have presented different definitions for property that are articulated in the following. In Shiite jurisprudence, property defines every object whose possession is possible. It should have the capability to be possessed and owned at first. Second, people should take its advantages. First condition id the ownership capability for a person or a group of people. Second condition is the state of being useful. In other words, the object is called an object when it is useful for human beings and fulfills their material or spiritual demands (Ibrahim Yek, 1936). Thus, the religion has prohibited trading a useless object that has not the capability to be possessed by individuals. One condition for object of sale is its capability to be a property (Khomeini, 2000). Ayatollah Khoei described property as, "property is an object that one pays for it and demands to have it" (Khoei, 1991). The author of Miftāh al-karāmah has stated "المال ماييذل فى مقابله المال" property is an object that one pays a valuable thing for it" (Hosseini Amelli, 2004). It seems jurists have presented many definitions for property; but all definitions refers to one issue that the proper enjoyment of a property shall be permitted and people will become rich by the property; it has a price in the market and its waste requires compensation (Sharaf al-Din, 1983). In addition to the mentioned items, property has religiously two important constraints.

1) The holy lawgiver has not boycotted it; therefore, property should have legitimate benefits and object lacking legitimate benefits (like wine and pig) are not called a property in Islam (Khoei, 1991).

2) Property should have proposed profits; therefore, it is boycotted by religion if it has trivial or rare benefits.

\section{Legal Definition of Proprietary Value}

Legal experts have presented several definitions for proprietary value that are described in the following:

Property is a useful object that has economic and trading value; it is not necessary for a property to have tangible and material value because rights with economic and financial values are regarded as property (Safaei, 2005). Moreover, two conditions are predicted in the legal definition of property:

1) It should be useful and fulfill material or spiritual human needs.

2) It should have the capability to be possessed by a particular person or nation.

Therefore, although some objects like free seas, sun, and air are the natural necessities and life requirements, one cannot regard them as property because any exclusive ownership claim for them is rejected. In past, only material goods were regarded as property. Nevertheless, with the advances in science and technology, all elements such as receivables, financial rights, patents, and goodwill are regarded as property (Katouzian, 1997). Iran's civil code and other laws in Iran have not presented any clear definition of property and presentation of a comprehensive definition is required. If a court issue a sentence and the related executives cannot find any property except goodwill while the victims request for seizure of the goodwill, the executive may confuse whether regard goodwill as property or not and whether they can seize the goodwill or not. This problem may raise in relation to notarial executions or tax executions (Jafari Langroodi, 2001). With these lines, the sensitivity of recognizing property is more evident and more palpable. In Article 348 of the Civil Code, proprietary value has been used as a synonym for reasonable profit and it disregards an object without reasonable profit as a non-property. However, it is necessary to devote a single article in the civil law to this issue. 


\section{Types of Property According to the Nature of Objects}

Property has several implications and includes all objects and elements while they are different in terms of nature and essence. Moreover, rules and regulates related to possession, transfer, and occupation of properties varies according to their nature. Recognition of many civil sentences depends on identifying the type of property as the subject of obligation or contract. For instance, it is said about a sale contract that the subject should be a real object; it is profit about renting and transfer. Thus, it is necessary to determine the type of property for determination of the type of contract (Katouzian, 1997). With respect to their nature, each property is placed in a specific form of contract. Some types of objects are as following:

\subsection{Real Property}

In law and jurisprudence, real property is an object with material external existence such as house, car, land etc.; it has different types including specified good, a specified whole, and a whole in liability.

\subsection{Profits}

Profit refers to the benefit earned from a property without any reduction from the substance of the real property such as fruits, sheep wool, etc. (ibid: 37). Profits are classified in different groups by legal experts as following:

\subsubsection{Natural Profits}

They are the benefits earned naturally without any interference of human work or human intellect such as vegetables.

\subsubsection{Artificial Profits}

These profits are not available in nature; human work or intellect has invloved in their production such as wheat and barley that are the result of cultivation.

\subsubsection{Civil Profit}

These profits are regarded as advantages by civil law. They are not derived naturally from a property but they are the result of a contract or a property as the subject of contract such as the profits of renting and the profits earned from life estate, right for a prescribed period, residence, and endowment.

\subsubsection{Material Profits}

They are the profits in material forms such as fruits when they are picked up and independent of the tree; when they are in fruit shop. The grass of plants is material profits as long as they are attached to the plant but after their independency of the plant, they are not regarded as profit (Jafari Langroodi, 2001).

\subsubsection{Intellectual Profits}

As it is called also as reasonable profit, it is tangible profits since stipulated in Article 348 of the Civil Code, "The sale of something of which ... can bring no reasonable profit". In other words, any profit attracted a considerable group of reasonable persons is called intellectual profits. In this manner, the use of watching animals in zoo in our age is an intellectual profit (ibid: 62).

\subsubsection{Attachable Profits}

Attached profits are the attributes or qualities causing the valuation of an objectand they cannot be imagined separate from their own substance such as animals' fattening and the increase in its price due to the fattening; since increase in the price of the the animal depends and attached to its fattening. This is true about the price of a good or land as their attributes are attached profits. Articles 786, 804, 819, and 287 of the Civil Code are stipulated in this regard. Article 287 of the Civil Code stipulates, "Separable accretion and usufruct with accrues under a contract between the time of its being made and its cancellation shall belong to the party who under the contract has become the owner. But usufruct which is an integral part of the property dealt with under a contract belongs to the party who owns the property after the cancellation of the contract." It should be noted that this rule is executed for every property that a person owns it for a certain time as this rule is executed when the sale contract is terminated or it is voided before maturity due to waste of the sale contract (Katouzian, 1995).

\subsubsection{Separable Profits}

The profit that can separate legally or materially from the substance of the real object; its value can be calculated apart from the real object. The value can be transferred to another party such as the fruits of a tree or the child of an animal. The important result of such division reveals when the real object is possessed by the transferee and there is a trial about its termination or producing. The ownership returns to its first position due to termination or revoking a sale contract. In this situation, if the profits are attached, they are transferred along with the real 
object; if they are separable, profits belong to the person who owned the real object at the time of producing the profit. For example, if a garden is sold and the parties terminate the sale contract after one year, the fruits of the current year belong to the buyer and it belongs to the seller since the rescission. If the price of real object increases due to the presence of fruits, the buyer has no right for the increase (Jafari Langroodi, 2001).

\subsection{Depreciatory Property and Non-Depreciatory Property}

Depreciatory or consumable property signifies the real objects that will be vanished at a time not so long with using it; there is often no separation between this type of real property and its profits. Therefore, taking its advantages causes the vanity of the property such as food, fruits, and drinks. Non-depreciatory properties are not disappeared soon due to consumption but they have a long stability. It is possible to separate essence and the profit from such properties and the profits can be used independently while the substance remains. In terms of loan and endowments, jurists refer to such properties; they argue that the two religious contracts cover non-depreciatory properties. However, after using the profits, the substance of non-depreciatory properties remains and their consumption does not result in their vanity. Although they may decline or become old due to usage (Emami, 2015).

\section{Property Recognition Criteria}

This section focuses on the criterion for proprietary value. The important issue issue is whether to regard people's judgment as the criteria for proprietary value or regard the idea of a specific person about proprietary value and as the measure. If the general measure is accepted, trading objects with profit to one person but not to the public is null. If the personal os regarded, the transaction is correct and the wills of parties are effective. The two ideas have several proponents.

\subsection{Personal Criterion}

Some jurists argue that if an object is useful for a person (although it may be in a specific time and place) and fulfill his demands, it has proprietary value, and it is regarded as property. Thus, the measure for determining an object's proprietary value is the person's relish and idea. Jurists proposing the personal state of proprietary value have paid attention to individuals' various needs and they claim that individals' motivations and needs vary. For an object regarding as property, it is not necessary to meet attention and relish of individuals. If an object ensures profits for one person in a society, it has proprietary value (Tabatabaei, 1991). Some jurists believe that personal purpose is indeed the public purpose because each member of the society placing in the position of this person will require the property and the object satisfies his demands. In other words, if the ordinary people and wise people are placed in his position, they find the object valuable and they are ready to give some part of their assets in exchange for it; this is a rational action. Therefore, the environmental conditions as well as personal and social situations with their diversity have conveyed a relative implication for proprietary value. The relativeness is resulted from having profit and being limited to the offer. An object may be valuable for a specific person in certain times and places while it is not valuable for common people in normal situation such as a family picture or the air in the atmosphere of earth that is found much in atmosphere but it is little in under sea or ocean. Since it is little, it is be valuable; hence, it has proprietary value and its transaction is correct (Shahidi, 1998). Consequently, the measure should be accepted according to the diverse needs of people in current societies. It is very important for the object to fulfill the needs of individuals; as the object is profitable for a person, he can occupy it in the framework of one contract providing that the legislators have not prohibited its occupation or trading. Since its legal and religious profits, there seems to be no sign that it is irrational.

\subsection{Public Criterion}

Some jurists believe that personal criterion cannot be regarded as a measure for having proprietary value; but

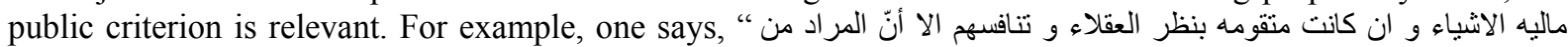
"العقلاء نو عهم دون الثخص الواحد,", the proprietary value depends on the idea of reasonable persons and their attention or demand is relevant; however, the type of rational people are intended not a person of a community (Naraqi, 1994).another person says, "فكلما جازت الوصيه به لكونه مقصودا بالانتفاع للعقلاء فينبغى جواز بيعه", every object with reasonable estate and can be transferred by will has the capability to be set as the subject of transaction contract

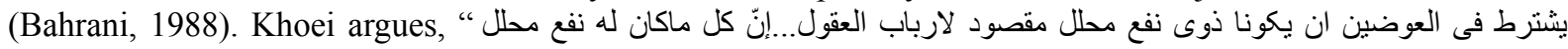
"مقصود للعقلاء فانه يجوز بيعه و التجاره فيه , the considerations of a transaction should have a profit admitted by reasonable persons. Every object with legitimate profit for the reasonable persons has the capability of correct and permitted sale contract (Khoei, 1991). Sheikh Ansari defines the valid profit in proprietary value as one validated by reasonable persons as it is considered by reasonable people in a community, “ النفع المعتبرفى صدق المال "هو ماكان...معتبراً فى نظر العقلاء (Ansari, 1997). Of course, every object with legitimate religious profit can be subject of transaction if the profit is considered by the reasonable people although the profit might be few and 


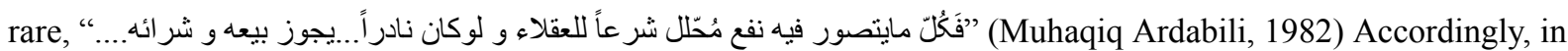
order to satisfy conditions for correctness of a transaction, it should have considerable profit from the viewpoint of reasonable people; it is not satisfied without considerable profit from the viewpoint of reasonable people and the transaction will not be correct. When an object has a predicted profit and the profit is not prohibited, one can not issue a sentence about the illegitimacy of the object because the axiom for correctness of a transaction is the

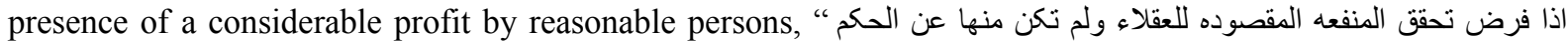
"بحرمه الاكتساب فان الدارو جود المنفعته التى يتوجه العقلاء اليها مع حليتها شرعا (Khansari, 2008). Muhaqiq Thani has regarded the permission to sell and buy a real property as proprietary value; ownership depends on the fact that the real

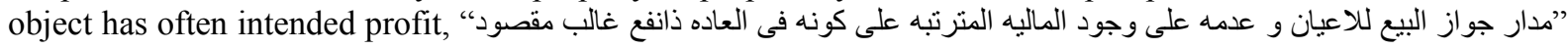
(Thani, 1993). With regard to the past content, the validity of proprietary value depends on the type of people devoting the object in exchange for the property; customs also pays attention to this issue. In general, custom disregards trivial considerations might be used to deviate the rules governing contracts and they have formalized shapes.

\subsection{Criterion to Determine Public or Personal Status}

In terms of the mentioned public and personal criteria, one may ask which crietion shall be included in judgements, whether all individuals are liable to be set as criterion or a group of people are liable; or even the usefulness for only one person is valid. In respond, it should be stated that law has predicted no specific stipulation. Article 215 of the Civil code states, "The object of a contract must be capable of being owned and must embody some reasonable and legitimate advantage" and Article 348 of the Civil code argues, "The sale of something of which the sale or purchase is by law forbidden, or which is not (describable as) property or which can bring no reasonable profit or which is not within the seller's power to deliver is null and void unless the purchaser himself is able to take possession of it." Moreover, Article 637 of the Civil code stipulates, "Any thing which is capable of yielding a profit while continuing its own existence unchanged is capable of being loaned." Carefully review of these articles suggests that the legislators emphasize on reasonable profit. As a legal expert, Shah Bagh explains Articles 215 and 348 of the Civil Code and asserts, "The subject of transaction may be a property including either general or in-loan, either with external objective reality or not, or an action may be the subject of a contract" (Haeri Shahbagh, 1997). In all transaction, the subject of trade must have proprietary value. In Article 215 of the Civil Code, proprietary value is suspended to having profit accepted by reasonable persons. Consequently, selling and buying a grain of wheat or millet (although it may be a personal asset) is null since it has no proprietary value. In the same manner, selling and buying creeping animals, predator animals, and insects are null. According to Article 215 of the Civil Code, subject of obligation should have trading capability; it means it should have the capability of being exchanged and transferred to money. Most scholars believe that this idea should be revised because there are som objects without a price but they are subjects of a trading due to specific attributes or reasons such as a document or a family picture for the members of the family while it is not regarded as property by others (Katouzian, 1986). According to the expressed views about Article 215 of the Civil Code, it should be accepted that the usefulness of an object (even if it targets only one person) is set as the basis for considering proprietary value if the usefulness is confirmed by reasonable persons. On the one hand, the expression of law about usefulness is absolute, it has not mentioned anything about public or personal criterion, and it seems no necessity to have a profit for majority or common people. On the other hand, the needs of person cannot be disregarded as it is belongs only to him. Attention and focus on legal principles such as the principle of prima facie validity of contracts can prove the validity of transaction even when it is profitable to only one person. Consequently, the correctness of such contracts is associated with the personal criterion and rejection or confirmation of reasonable persons is irrelevant; the example of family picture clears this issue. The appearance of the expression indicates confirmation or null of the transaction in relation to all persons that cannot even use it. Accordingly, these transactions are relative with respect to the principles and rules. In other words, it is null for the persons who cannot use it but it is correct for individuals that can use it because it meets the principle of prima facie validity of contracts. As a result, social logic, facilitation of trade, and the principle or will governance affirm that the transaction is correct and effective in terms of proprietary value. Some Shiite jurists have accepted this idea (Safaei, 2005).

\section{Conclusion}

Shiite jurists believe that an object of sale not only must have value and trading capability in terms of custom, common sense, and common practices but also its enjoyment shall not be sanctioned religiously. In this regard, most famous Shiite jurists disregard proprietary value of objects and goods with rare or small profit; the sale of these objects is null although they may be useful rarely for specific persons. In contrast to this opinion, some jurists such as Imam Khomeini disagree this idea. Legal experts also oppose this idea and claim the proprietary 
value of rare profits. For facilitation of transactions and respecting to individuals, it is true to argue that every profitable object for which the members of society are ready to pay money has proprietary value and can be an onject of sale. Therefore, social logic, facilitation of trade, and the principle or will governance indicate that the personal criterion is regarded as the rule. Social clause of the ideas about proprietary value is customary value, which has been accepted by legal experts. Differential clause in proprietary value contains the proprietary value of abundant and free objects and the rare profits; most jurists claim lack of proprietary value for them and their sale is null but Imam Khomeini and legal scholars have regarded proprietary value for rare profitable objects and they assert that the rule of customs for issuance of sale permission is enough.

\section{References}

Al-Waseti, Al. (1985). Taj al-Arus Min Jawahir al-Qamus. Revival of Arab Heritage, Beirut, 23(1), pp. 321

Ansari, Sh. M. (1997). Al-Makasib. Al-Hadi Institute. Qom, Iran, 1(4), pp. 12.

Bahrani, Sh. Y. (1988). Al-Hadaiq al-Nazera for Ahkam Al-Etra al-Tahira. Islamic Publication Institute, Qom, Iran, Vol. 18, pp. 429.

Emami, S. H. (2015). Civil Law. Islamiyah Publication, thirty sixth edition, 1(4), pp. 22.

Haeri Shahbagh, S. A. (1997). The Description of Civil Code (Vol. 1, pp. 358). Tehran: Ganj-e Danesh Publication.

Hosseini Amelli, S. M. J. (2004). Miftāḥ al-karāmah fì sharh Qawā'id al-'allāmah. Alal Bayt Institute (Vol. 4, pp. 222). Qom, Iran.

Ibrahim Yek, A. (1936). Legitimate financial transactions (9th ed., Vol. 4, pp. 5). Egypt.

Jafari Langroodi, M. J. (2001). Laws for Properties. Ganje Danesh. Tehran, fifth edition, 4(1), pp. 34.

Katouzian, N. (1986). Civil Law (General provisions of the contracts). Dadgostar, Tehran. Behshahr Publications, Tehran, 2(1), pp. 314.

Katouzian, N. (1995). Civil Law (Property and Ownership) (Vol. 149). Dadgostar, Tehran.

Katouzian, N. (1997). Possession and Property. Dadgostar, Tehran, 4(1), pp. 9-10.

Khansari, S. A. (2008). Jame al-Madarik fi Sharh al-Mokhtasar al-Manafe (Vol. 4, pp. 12). Sedouq School, Tehran.

Khoei, A. (1991). Misbah al-faqāhah fĩ al-mu'āmalāt. (Eds.) Mirza Muhammad Ali Tawhidi. Darolhadi, Beirut, 2(1), pp. 3.

Khomeini, S. R. (2000). Al-Bay'. The Institute for Compilation and Publication of Imam Khomeini's works (1st ed., Vol. 4, pp. 25). Tehran.

Muhaqiq Ardabili, A. (1982). Majmaol Faeda wa al-Borhan. Islamic Publication Institute, Qom, Iran. 7(1), pp. 53.

Naraqi, A. (1994). Shia Documents. Institute for Revival of Alal Bayt Heritage, Qom, 2(1), pp. 429.

Safaei, S. H. (2005). Civil Law: Individuals and Properties. 1(2), pp. 123.

Shahidi Tabrizi, M. F. (1996). Guide for religious students. Etelaat, Tabriz, 148(1), pp. 20.

Shahidi, M. (2011). Civil Law: Formation of Contracts and Obligations. Majd Publication, Tehran, 1(4), pp. 303-304.

Sharaf al-Din, A. (1983). Al-Ahkam al-Shariya le A'mal al-Tabiiya. Kuwait, 4(2), pp. 94.

Tabatabaei Yazdi. S. A. (1991). Riyāụ al-masā'il fĩ bayān al-ạ̣kām bi-al-dalā’IL. Drilhadi, Qom, Iran, 4(1), pp. 14.

Tarihi, F. (2000). Fi Zawaid al-Mo'jaiin. Roshd School, Al-Riyadh, 3(1), pp. 363.

Thani, Sh. A. (1993). Jame al-Maqasid fi Sharh al-Qawaid. Alal Bayt Institute, second edition, Al-Tarath. 2(1), pp. 12.

\section{Copyrights}

Copyright for this article is retained by the author(s), with first publication rights granted to the journal.

This is an open-access article distributed under the terms and conditions of the Creative Commons Attribution license (http://creativecommons.org/licenses/by/4.0/). 